\title{
РАССМОТРЕНИЕ СВОЙСТВ ЛИЧНОСТИ В СТАРШИХ КЛАССАХ БОЛГАРСКОЙ ШКОЛЫ С ИНТЕНСИВНЫМ ОБУЧЕНИЕМ РКИ
}

\author{
Люба Станева \\ TEACHING PERSONALITY TRAITS TO STUDENTS IN BULGARIAN HIGH \\ SCHOOLS WITH INTENSIVE TEACHING OF RUSSIAN \\ AS A FOREIGN LANGUAGE \\ Lyuba Staneva
}

\begin{abstract}
The article discusses aspects of teaching Russian as a foreign language when working with texts of different genres and degrees of adaptation in the Bulgarian high school in the first year of Russian language teaching and demonstrates a variety of techniques and methods of working with a text.

The author suggests a well-motivated staged introduction to literature in Russian for the purposes of language, literary and moral education. The proposed sequence involves not only the creation of specific semantic sets on the topic of "Character", the ability to use stable phrases, grammatical and syntactic constructions, but also the formation of certain psychological properties and traits, moral criteria. The suggested staged approach for working on the topic contributes to the development of speech and cognitive skills.
\end{abstract}

Key words: RFL, work with text, adolescent thinking, personality traits, morality

DOI: https://doi.org/10.46687/LWLF3285

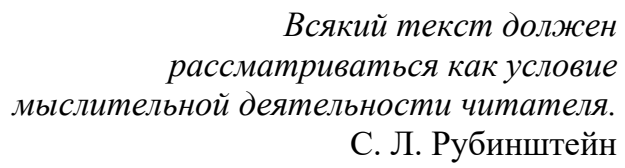

Работа на уроках иностранного языка (ИЯ) связана с работой над текстами, в ходе изучения которых учащиеся сталкиваются с многими насущными проблемами жизнедеятельности и реализации личности. Среди них выделяются такие, как проблемы толерантности, проблемы современной семьи, проблемы совести, проблемы материализма и национальной культуры, проблемы нищеты и борьбы с ней и др. Таким образом, на уроке ИЯ, выясняя для себя понятия, задумываясь впервые над сложными человеческими проблемами, строя свой личный нравственный мир, учащийся организует свой собственный способ взаимодействия с миром. 


\section{Годишник на ФХH, XXXII A}

Подготовка учащихся к последующему участию в процессе межличностного и межкультурного взаимодействия через обучение иностранному языку предлагает и исключительный педагогический потенциал духовно-нравственного воспитания подрастающего поколения.

Нельзя не согласиться с мнением Т. М. Неустроевой (Neustroeva 2016: 40), что „воспитание является важнейшим преобразующим фактором общественного развития, а духовно-нравственное воспитание всегда формировало ядро личности, благотворно влияя на все формы и стороны взаимоотношений человека с миром“. Внимание к духовнонравственному воспитанию в условия х быстро развивающегося общества превратилось в один из самых важных аспектов социализации личности, в важный фактор постепенного вовлечения молодого человека в различные сферы общественной жизни. Вот почему вопрос об усвоении учащимся языковых форм, норм и явлений иностранного языка в период становления и развития собственной личности и ее нравственного стержня в условиях другой социокультурной среды, был, есть и будет очень актуальным в методике преподавания ИЯ. Доказательством тому являются многочисленные исследования многих авторов.

Потенциал формирования коммуникативной компетентности в процессе изучения иностранного языка в условиях школы и вуза рассматривается в публикациях Е. И. Пассова (Passov, Kuzovleva 2010) и др. Исследованию сущности, особенностей духовного развития, духовно-нравственного воспитания посвящены работы Т. И. Власовой (Vlasova 1999/2005), которую занимал механизм перевода абсолютных ценностей в смысл жизни конкретного ребенка. Другой взгляд на духовность и ее роль был предложен С. Б. Крымским (Kryimskiy 1992), для которого духовность предполагает выбор своего собственного образа жизни, своей судьбы и роли, встречи с самим собой, т. е. она - способ „самостроительства” личности. А. Ф. Никитин (Nikitin 1980:), с другой стороны, в связи с нравственным становлением личности, рассматривал особенности несовершеннолетнего подростка с точки зрения формирования ответственности в нем.

Значительный вклад в изучение психологических механизмов творческого развития личности внесли Б. М. Величковский (Velichkovskiy 2008), который работает в области прикладных исследований познавательных процессов, Ж. Пиаже (Piazhe 2004), создатель теории когнитивного развития, С. Л. Рубинштейн (Rubinshteyn 2002), чья широта и энциклопедичность теоретических обобщений, 
охвата исторического и экспериментального материала лежат в основе современного изучения общей психологии и конкретно ребенка, Л. С. Выготский (Vyigotskiy 2005), основатель деятельностного подхода в обучении, чьи идеи и взгляды, опередившие время, соединили педагогику и психологию и заложили основы одних из самых передовых подходов в современном обучении. Р. Солсо (Solso 2006), раскрывший теоретические и эмпирические основы когнитивной психологии.

Следует отметить, что в последние годы все чаще внимание ученых направляется на формирование метакогнитивных стратегий овладения иностранным языком, которые „нацелены на наблюдение и управление использованием когнитивных стратегий и представляют собой последовательность действий, обеспечивающих планирование и контроль познавательных процессов, а также соотнесение их результатов с целями деятельности“ (Evdokimova 2018: 332). Они рассматриваются как необходимая основа процессов развития личности учащегося, т. к. связаны с выявлением целей собственной интеллектуальной деятельности, с учетом последствий принимаемых решений, с объективной оценкой собственного знания/ незнания, с аргументированием собственных интеллектуальных поступков. Обучение этим умениям позволяет учащимся активно составлять программу собственного учения, выявлять свои сильные и слабые стороны; осознавать, что именно увеличивает эффективность усвоения для них ИЯ. Использование метакогнитивных стратегий на уроке включает обучение учащихся различным стратегиям учения, методам самоконтроля, переносу успешных стратегий в новые учебные ситуации, что приводит к активизации познавательной деятельности и формированию способности учащихся к самооценке на пути овладения ИЯ. В настоящее время предлагаются разные методы обучения метакогнитивным умениям (,экстернализация“, ,„рефлексивный диалог“ и др.), а не указывается единственный наилучший метод. Это предоставляет возможность учитывать, что различные типы обучаемых (со своими индивидуальными способами учения) требуют и различной организации методического взаимодействия. Следует сказать, что хорошо подготовленный педагогический специалист в области иноязычного обучения заранее намечает целенаправленную последовательность воздействия на обучаемых в целях достижения развивающих педагогических, методических, дидактических решений задач обучения языку. 


\section{Годишник на ФХH, XXXII A}

Мы полностью разделяем мнение Желязковой (Zhelyazkova 2018: 90), что „использованные учебные материалы и дидактические методы должны отражать всю сложность и многообразие (психологическое, социолингвистическое, национальное, культурное) человеческой коммуникации, чтобы добиться желанного уровня коммуникативной компетенции.“" Мы считаем, что первостепенная задача преподавателя в этом плане - предлагать разнообразные обучающие стратегии, которые способствовали бы развитию каждой разновидности компетенции.

Осуществлению этих целей способствуют интерактивные методы обучения, важность применения которых исследует И. Иванов (Ivanov 2005:16) и мы придерживаемся его мнения, что „учеников нужно стимулировать создавать связи между событиями и объектами, применять принципы дивергентного мышления в решении проблем, принимать интеллектуальный риск в решении проблем.“2 Основой активизации учащихся при применении данных методов является целенаправленное взаимодействие между учителем и учениками (работа в диалоге, в команде) в котором ценна не только передача знаний, но и превращение учеников из пассивных получателей знаний в активных конструкторов собственных знаний. Задача учителя - создать условия для инициативы детей. Использованная методика не стандартная, а „гибкая“, приспосабливающаяся к каждому ученику.

Другая возможность добиться желаемых результатов в обучении ИЯ это интенсивные методы, основоположником которых является болгарский ученый Г. Лозанов (Lozanov 1973/1977). Их основная задача - в условиях дефицита времени овладеть иностранным языком как средство общения и познания. Соблюдая принципы данной методики, преподавателю нужно убрать стрессовость с процесса обучения, дать возможность осуществить его как на сознательном, так и на несознательном уровне, задействовать все резервы сознания, чтобы повысить результативность.

Целью публикации является целенаправленное исследование совмещения методики преподавания иностранного языка и нравственного воспитания учащихся подросткового возраста с упором на формирование нравственных устоев школьников.

\footnotetext{
${ }^{1}$ Перевод мой.

${ }^{2}$ Перевод мой.
} 


\section{Люба Станева. Рассмотрение свойств личности ...}

В данной публикации обосновывается определенная эффективность работы над развитием критического мышления, понятийного аппарата и нравственного мировоззрения обучаемых подростков на уроке РКИ (русского языка как иностранного) одновременно с развитием умений и навыков владения русским языком. На основе продуманной последовательности преподнесения текстового материала и работы с ним рассматривается авторская система заданий, которые приводят к решению комплексных задач обучения.

Указанная технология работы над лингвокультурной и познавательной компетенциями обеспечивает максимальную приближенность процесса изучения иностранного (русского) и родного (болгарского) языков, что значительно облегчает усвоение иностранного языка и содействует становлению личности подростков.

Знакомство с иностранным языком и его овладение в подростковом возрасте сопряжено с определенными трудностями для участников учебно-познавательного процесса. С одной стороны, со стороны подростка - преодоление эмоциональных, интеллектуальных и нравственных трудностей взросления и приложение постоянных усилий в овладении знаниями. И с другой - выбор и приложение преподавателем эффективных педагогических и методических приемов на уроке, где в процессе иноязычного общения есть возможность и необходимость влиять и на формирование социально-ценностных качеств личности.

При работе в старших классах, даже на уроках преподавания иностранного языка, перед преподавателем, на наш взгляд, стоит вопрос о важнейшей особенности подросткового возраста, когда осуществляется интенсивное нравственное, социальное, интеллектуальное формирование личности и психологическое развитие. Именно поэтому преподавателю необходимо понимать все тонкости становления личности современного подростка и учитывать их при работе на уроках РКИ с текстами, предлагающими разные точки зрения, разные типы психологического строя характера героев, разные взгляды на жизнь, т.к. „правильно выбранный художественный текст позволит мотивировать учащихся к изучению русского языка, сделав занятия интересными, увлекательными, личностно значимыми для них“ (Brodzeli 2017: 94).

Преподавателю следует иметь в виду определенные особенности подростка, которые приобретают в период взросления особую важность.

1. В психологическом плане

У подростка возрастает потребность в осознании и оценке своих личных качеств и выработке тех черт, которые позволяли бы добиваться 


\section{Годишник на ФХH, XXXII A}

успехов, а также растет потребность найти свое место в коллективе. Вот почему в работе преподавателя появляется необходимость учитывать, как формирование и развитие самосознания подростка накладывают отпечаток на всю его психическую жизнь, на его учебную деятельность, на формирование его отношений к окружающему, его взаимоотношений с людьми.

Преподаватель, заботящийся о развитии личностных качеств подростка, на наш взгляд, должен направлять к осознанию ценности собственной личности, к выяснению и выработке определенных моральных критериев, к формированию навыков приспосабливаться к разным жизненным сценариям (в том числе и на иностранном языке), исходя из основных принципов работы с текстом на уроке и индивидуализируя эту работу с каждым учеником.

2. В интеллектуальном плане

Очень важно иметь в виду, что в этот период „в подростке меняется соотношение между конкретно-образным и абстрактным мышлением в пользу последнего“ (Podlasyiy 2004: 68). Таким образом, обучаемые готовы рассуждать над причинами поведения людей, искать правильные для себя ответы на вопросы, связанные с взаимоотношениями, и создавать свои нравственные правила на основе своего опыта и опыта работы с текстом.

Учащиеся этого возраста уже развивают в себе умение выделять и изучать отдельные свойства сложного предмета, выдвигать и проверять гипотезы.

И тогда возникает возможность создавать у них навыки рассуждать над сложными вопросами и использовать когнитивную догадку, т. е. ученики уже готовы получить активное обучение умениям:

- видеть причинно-следственные связи между явлениями;

- выявлять разницу между верным и неверным утверждением;

- проявлять креативность.

В условиях изучения иностранного языка эти умения лучше всего, по-нашему мнению, выявляются и развиваются на основе работы с текстом. Нельзя забывать, что интеллектуальное усилие декодировать многоаспектный материал текста это и способ познания глубины культуры, литературы, человеческой сущности, это и возможность поработать над самоосознанием себя.

Необходимо подчеркнуть, что именно таков и современный взгляд на обучение как мыслить - нужно думать системно, критически, свободно, самоактуализирующе. 


\section{3. В нравственном плане}

Подростковый возраст - возраст открытий, экспериментов, когда выявляются и устаиваются нравственные позиции. Но мировоззрение, нравственные принципы и идеалы, система оценочных суждений еще не очень устойчивы в молодых людях - их могут поколебать противоречия жизни, мнения друзей, сложность ситуации. Поэтому немаловажной частью правильной организации нравственной системы подростка в школе, мы считаем, является рассмотрение определенных нравственных категорий в контексте разнообразной работы с разными текстами.

Необходимость обогащать нравственный опыт подростков, который во многом определяет как будет складываться их личность, как конструктивно общаться, чтобы эффективно решать задачи в процессе жизнедеятельности, и факт функционирования в новом классе (построение взаимоотношений с новыми одноклассниками после второго этапа обучения в болгарской школе) предопределяют выбор тем текстов на уроках РКИ в 8 классе с интенсивным обучением языку - основным, на наш взгляд, становится вопрос о рассмотрении свойств личности.

Согласно словарю Безруковой - свойства личности это „характерные признаки поведения, выражающиеся как его качественная сторона, имеющие тенденцию к устойчивому проявлению, повторяемости в сходных ситуациях, четкой выраженности. Они формируются посредством накопления индивидуального опыта в процессе воспитания и образования и способны к изменениям, усилению или затуханию" (ODK 2000: 696).

Свойства личности предопределяют как проявляется человек в своей деятельности и включают: темперамент, волю, эмоции, характер, мотивацию и особенности поведения.

Факторов, влияющих на формирование свойств личности, много, но одним из основных, является знакомство с языком (родным и иностранным) в условиях коммуникативно-познавательной деятельности школьника, где по словам Тер-Минасовой возникает „перекресток культур” (Ter-Minasova 2000: 255), а оно невозможно без знакомства с литературой на данном языке.

Понимание культурного пространства изучаемого языка (родного и иностранного) не возникнет без внимания к душе, к характеру носителей языка, где чувства и эмоции занимают главенствующее место (что близко и знакомо каждому человеку, даже подростку) и легче всего произойдет это при чтении и обсуждении художественных текстов в школе. Взгляд на практику в современной болгарской школе показывает, 


\section{Годишник на ФХH, XXXII A}

что в последние годы хотя и признается особая роль обучения русской литературе в системе преподавания РКИ, мало еще болгарских авторов учебников и пособий обращаются к кладу литературы и включают такие тексты в свои работы.

Все сложные деятельности по осмыслению культурных и лингвострановедческих особенностей можно и нужно осуществить, перешагивая барьеры в употреблении иностранного языка, таким образом максимально приближая процесс освоения родного (болгарского) и иностранного (русского) языков, что, на наш взгляд, облегчит выход учащихся в речь на русском языке.

Знакомство с литературными произведениями на иностранном языке еще на начальном этапе обучения языку, по нашему мнению, знакомит с языком во всем его многообразии форм и смыслов и способствует целостному пониманию учениками сложности развития человеческой личности, проникновению в душевный мир людей изучаемого языка, развитию речемыслительных навыков, необходимых в жизни вообще.

А работа с разными видами текстов на уроках позволяет, обучая грамматическим нормам, пополняя словарный запас учащихся, улучшая качество их речи, развивать умение анализировать, интерпретировать и создавать тексты различных стилей и жанров, что по сути дела, является творчеством, т. е. создаются условия для развития и творческого потенциала учеников.

Вот почему, на наш взгляд, текст является основой для создания развивающей среды на уроках иностранного языка.

В этом плане, на наш взгляд, исключительное значение приобретает определенная последовательность рассмотрения текстов (разного типа и жанра) о свойствах личности на уроках РКИ на начальном этапе, которая должна быть направлена на:

$\checkmark$ последовательное расширение знаний о качествах человека в принципе, на постепенное погружение в мир сложных нравственных выборов;

рассмотрение и оценку подростком собственного мира, на формирование психических свойств и черт личности обучаемого путем моделирования с помощью текста в условиях рассуждения, обсуждения, соревнования;

$\checkmark \quad$ работу на основе текстов, по темам, близким подросткам и связанным с качествами и недостатками характера человека, при которой 
на уроке постепенно вводится лексико-грамматическая и фонетикоинтонационная основа иностранного языка и делаются упражнения.

В следующей таблице - Схема 1. представлена последовательность работы с текстами, апробированная на уроках РКИ в Средней школе с языковым обучением (СОШПИЯ) им. Пушкина, г. Варна. В работе были применены разнообразные авторские упражнения, направленные на формирование познавательной и лингвокультурологической компетенции. Они объединены в комплексах тематически, применяются последовательно, следуют принципу дедукции/ индукции (в зависимости от сложности понятия в теме) и предлагают различные возможности осуществления логических операций, создания умений критического мышления и познания мира и человеческой личности.

Таблица иллюстрирует как, с нашей точки зрения, на уровне последовательного развития разных видов речевой деятельности и на уровне одного вида речевой деятельности возможно достижение комплексных целей преподавателя. В таблице представлен и тип текста.

Схема 1.

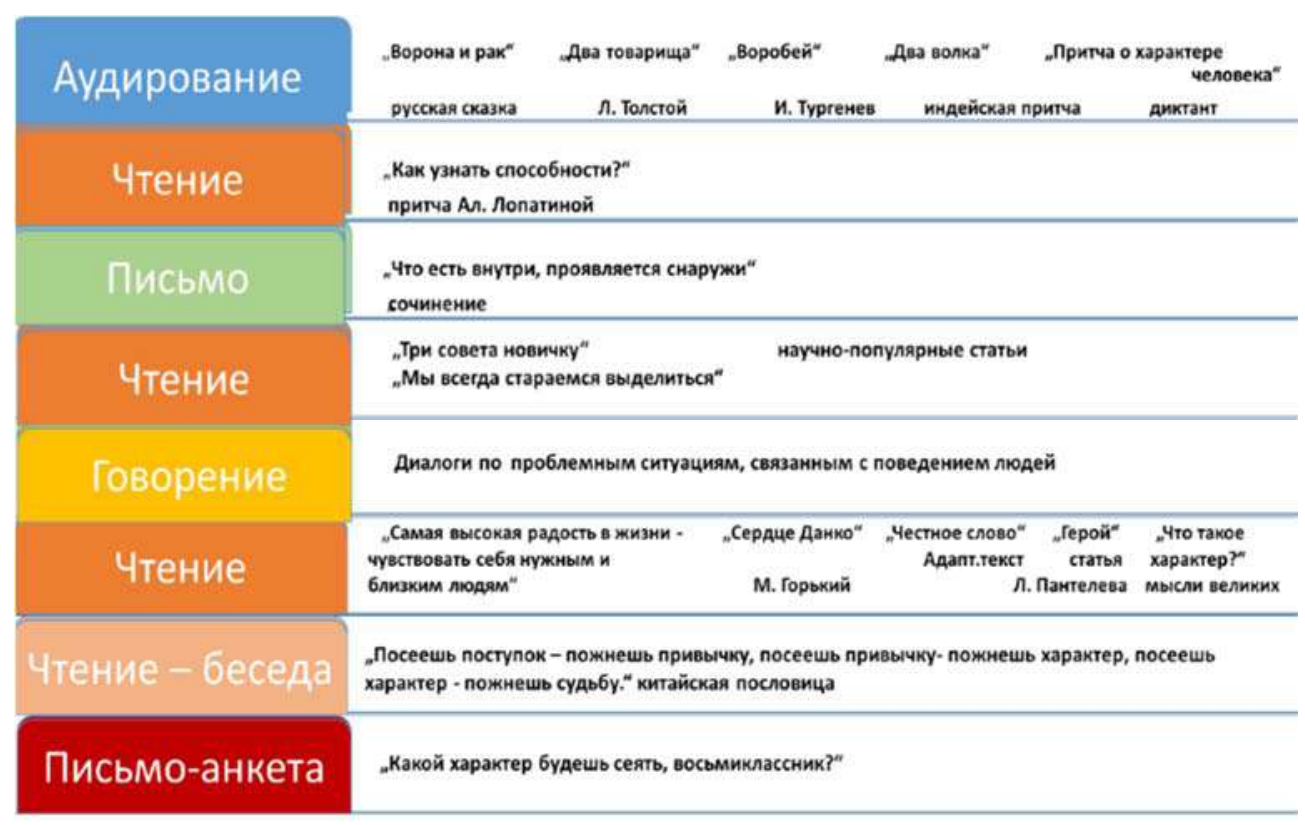




\section{Годишник на ФХH, XXXII A}

Выбор текстов и их последовательность предъявления учащимся тесно связаны с необходимостью постепенного наращивания лексического запаса и знаний по грамматике одновременно с поэтапным расширением понятийного аппарата учащихся. Вот почему в работе над конкретными текстами основными явились следующие понятия нравственности личности, которые рассматривались параллельно с работой над языком - Схема 2.:

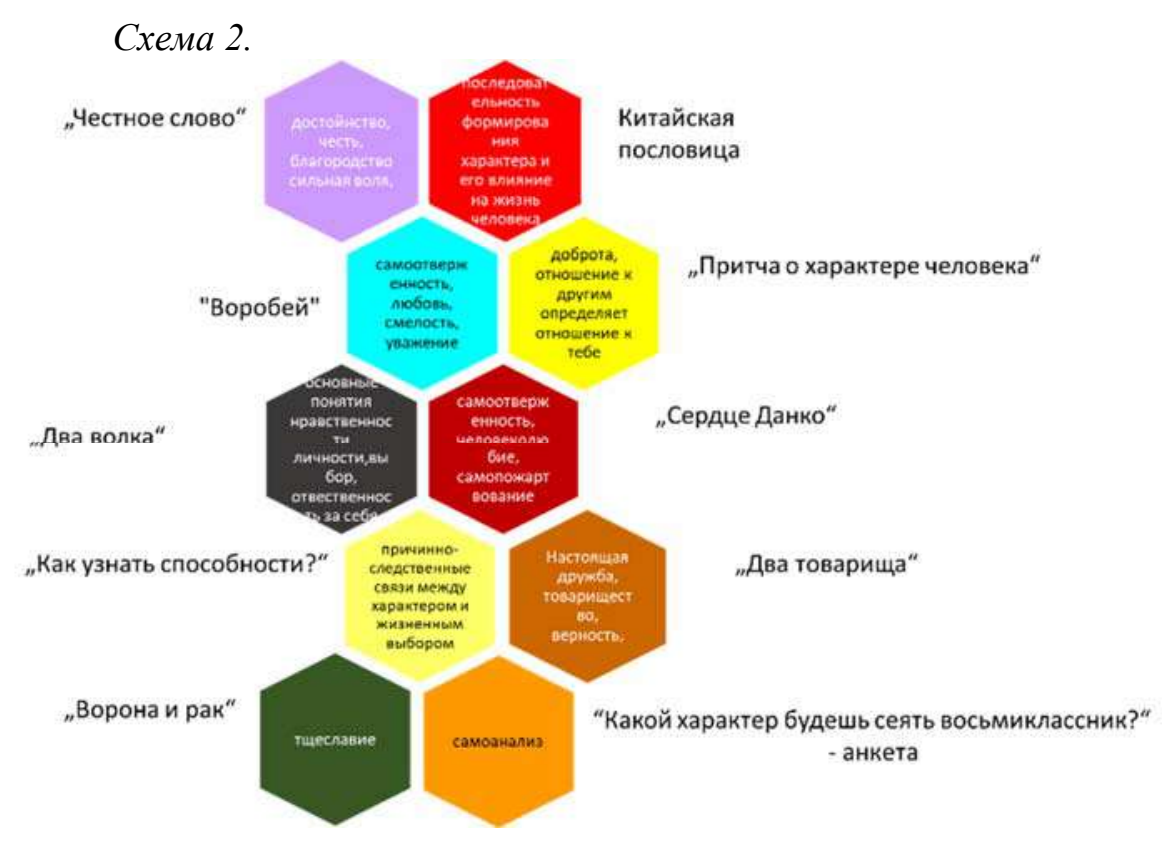

Важно отметить, что формирование психических свойств и черт личности учащихся при рассмотрении данных текстов развивалось, расширялось, раскрывая многоуровневость понятийного аппарата, эмоционального восприятия, нравственного созревания.

Потребность подростка осознать сложность собственного и окружающего мира, равно как и работа по языку, диктуют осуществлять работу над текстом особым образом. Мы полностью разделяем мнение Н. В. Кулибиной, что вместо комментариев и объяснений тексты должны быть снабжены „вопросами и заданиями, нацеливающими читателя на максимально самостоятельную работу: на вдумчивое чтение, смысловое восприятие чужого текста, его эмоциональное переживание, бережное освоение и выработку собственного обоснованного отношения к прочитанному” (Kulibina 2013: 72). 
Углубленное преподавание в концентрах обучения именно таким образом, согласно нашему опыту, приводит к:

- активизации самостоятельности мышления, что способствует умению выстраивать и реализовывать линии интеллектуального, нравственного, культурного, профессионального саморазвития и самосовершенствования;

- сопоставлению с собственными качествами со стороны учеников, что развивает возможности самоанализа и самокоррекции, приводит к лучшей социальной адаптации и к развитию в себе черты самореализующейся личности;

- развитию сопричастности, эмпатии, способности поставить себя на место другого, что способствует лучшему общению, умению работать в группах;

- пониманию учениками сложных причин поведения человека;

- исполнению воспитательных целей педагога для формирования нравственных идеалов и принципов у учеников;

- развитию в учащемся рефлексивной реакции в работе над языком - он сразу думает и отвечает на русском языке.

Как конкретно обучать этому на уроках РКИ? Руководствуясь, на наш взгляд, следующими принципами:

1. при работе над выбором текста - критериями выбора, нам кажется, должны быть:

- увлекательность;

- познавательно-воспитательная ценность;

- художественная ценность;

- возможность проявить креативность во время обсуждения, поискать новые решения проблемы, т. е. проявить сотворчество с автором.

2. при работе над языком - цель работы - создавать условия, максимально приближенные к способу освоения родного языка:

- восприятие на слух, подражание, потом освоение лексики, фраз, вдумывание, грамматика (в четырех видах речевой деятельности);

- быстрый темп речи с новым словом, фразой или грамматикой с многократными повторениями;

- динамика вопросов, требуемая быстрота реакции учащегося при затруднении фразу ответа начинает учитель), чтобы не было возможности подумать на родном языке (метод Каллана). 


\section{Годишник на ФХH, XXXII A}

3. при работе над содержанием - это должен быть разговор, в котором нужно предоставить возможность ученикам увидеть, как сложен мир; это обмен мнениями, в котором:

- преподаватель задает вопросы неоднозначные, побуждающие к рассуждению, к поисковой работе, к разговору и столкновению разных точек зрения, одним словом, к вдумчивому восприятию текста;

- последовательность вопросов следует принципу дедукции/индукции (в зависимости от сложности понятия в теме) и предлагает различные возможности осуществления логических операций, создания умений критически думать и познавать мир и людей;

- формируются навыки использовать когнитивную догадку

- дается возможность высказывать свою точку зрения, без опасения быть непонятым;

- формируются нравственные представления

- знакомясь с высокохудожественными образцами русской классики, уже можно начинать разговор о художественной образности.

Применение определенных методов, технологий и методических приемов обучения способствуют лучшей реализации принципов обучения, которые приводят к расширению основных направлений развития личности подростка - эмоциональное, интеллектуальное, когнитивное и психологическое.

В процессе знакомства учащихся с нормами иностранного языка (русского, в случае), учитывая все сложности подросткового возраста, стремясь к развитию личности каждого ученика, развивая понятийный аппарат обучаемых, закладывая знания об определенных нравственных категориях, преподавателю нужно очень тщательно приступить к выбору методических приемов для осуществления всех этих задач. Выбирая и применяя методы и приемы обучения, педагогический работник стремится найти наиболее эффективные методы обучения, которые обеспечивали бы высокое качество знаний, развитие умственных и творческих способностей, познавательной, а главное самостоятельной деятельности учащихся. В этом направлении он должен, по нашему мнению, следовать общей тенденции в развитии методов, а именно сближение разных методов в поисках оптимального варианта для конкретных условий обучения, что и применялось при работе с текстами в 8-ом классе болгарской гимназии в СОШПИЯ им. Пушкина. 
Иллюстрация общих требований к выбору методических приемов работы, которые нужно учитывать, на наш взгляд, представлена в следующей таблице - Схема 3.

Схема 3.

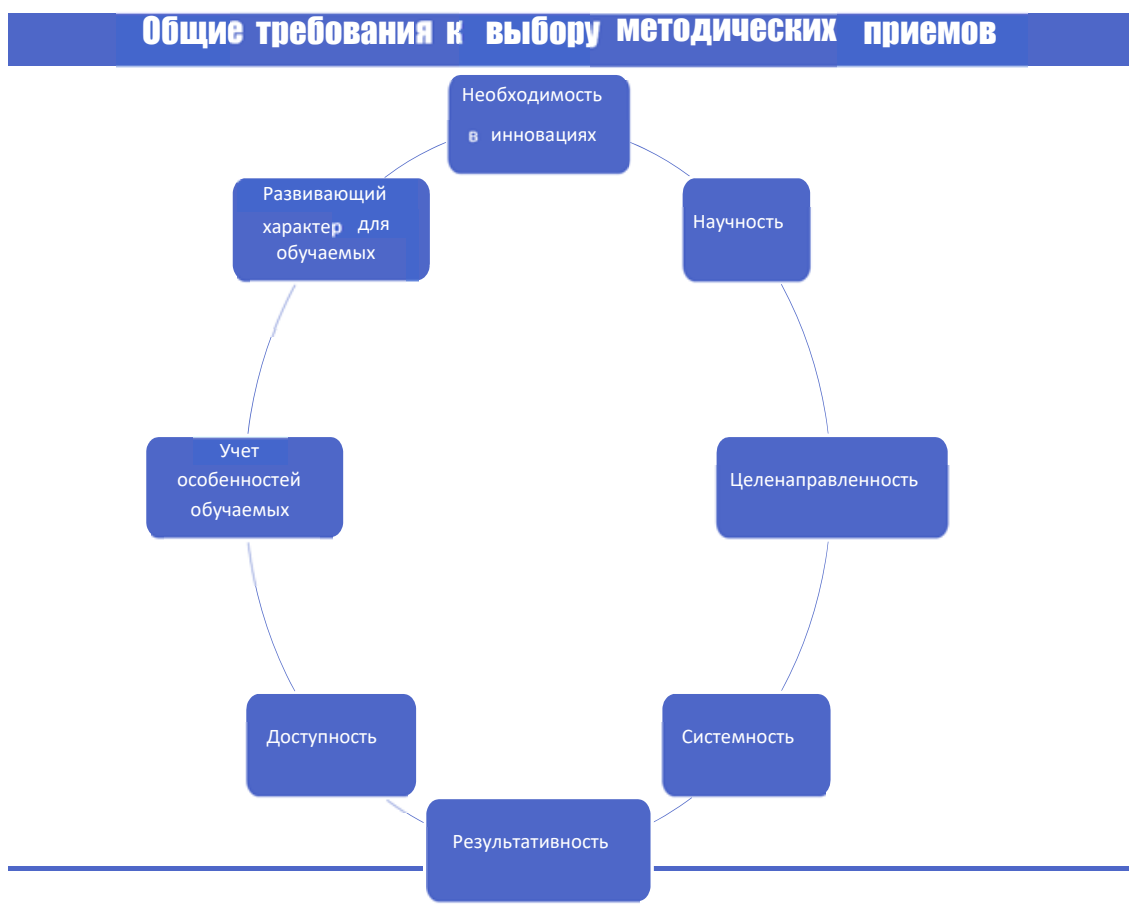

При выборе методических решений для достижения целей педагога, по нашему мнению, нужно руководствоваться в первую очередь необходимостью развивать учащихся с помощью инновационных средств работы. Это продиктовано современными вызовами времени - необходимостью в критическом и творческом мышлении, в способности думать и принимать решение под давлением обстоятельств и в кратчайшие сроки. Современная наука преподавания языка должна считаться с этим и как следствие заниматься:

- обучением нестандартному мышлению;

- учетом когнитивных возможностей учащихся;

- едиными для всего мира этическими основами образования 21ого века;

- развитием „гибких“ социальных навыков; 


\section{Годишник на ФХН, XXXII A}

- исследованием распространения билингвизма, полилингвизма;

- использованием информационно-коммуникативных технологий в образовании;

- инновационными подходами в обучении, основанными на исследовании человека.

Стимуляция познавательной деятельности на иностранном языке и умения активно формировать и защищать личную позицию, а также расширение творческих возможностей через индивидуализацию процесса формируют личность, отвечающую беспрестанно меняющимся условиям существования, что и является основной задачей школы сегодня.

Именно поэтому приобретает сейчас такое значение активное обучение $(\mathrm{AO})$ - одно из мощнейших направлений современных педагогических изысканий. По мнению исследователя В. Н. Кругликова, активное обучение представляет собой такую организацию и ведение образовательного процесса, которые направлены на всемерную активизацию учебно-познавательной деятельности обучающихся посредством широкого использования, как дидактических, так и организационно-управленческих средств и методов активизации (Kruglikov 1998: 308).

На современном этапе образования АMO (активные методы обучения) дополняют традиционные методы, посредствам которых позиция учащихся меняется с пассивно-потребительской на активнопреобразующую. Все обучаемые оказываются вовлечены в процесс познания, они имеют возможность понимать и рефлектировать по поводу того, что они знают и думают - обучающиеся учатся критически мыслить, решать сложные проблемы на основе анализа обстоятельств и соответствующей информации, принимать продуманные решения, участвовать в дискуссиях, общаться с другими людьми.

АМО могут использоваться на различных этапах учебного

\section{процесса:}

1 этап - первичное овладение знаниями, могут быть проблемная лекция, эвристическая беседа, учебная дискуссия и т. д.;

2 этап - контроль знаний (закрепление), могут быть использованы такие методы как коллективная мыслительная деятельность, тестирование и т. д.;

3 этап - формирование умений, навыков на основе знаний и развитие творческих способностей, возможно 


\section{Люба Станева. Рассмотрение свойств личности ...}

использование моделированного обучения, игровые и неигровые методы.

Одни из основных эффектов применения АМО связаны со становлением и развитием у обучающихся универсальных навыков, таких как:

- умение выслушивать и принимать во внимание разные точки зрения и мнения других людей;

- коммуникативные умения и качества;

- умения ясно формулировать сообщения и четко ставить задачи;

- способность принимать решения и умение решать проблемы;

- проявлять лидерские умения и качества;

- повышение интереса и мотивации к обучению у учащихся;

- изменение в положительную сторону отношения обучающихся к педагогу и к образовательному процессу.

В данной работе представлены некоторые современные актуальные методы, приемы и технологии работы с текстами.

\section{А. Методы}

1. Метод мозгового итурма (все тексты, на разных этапах изучения).

В основе метода быстрая реакция учащихся на определенное понятие с целью появления новых и оригинальных идей, решения проблем. Мозговой штурм эффективен тем, что развивает в учащихся способность к оперативному мышлению и включению в групповую работу, оказывает минимальное стрессовое воздействие, взращивает культуру коммуникации и развивает навык участия в дискуссиях.

2. Метод проблемного изложения, проблемной беседы (все тексты, на разных этапах изучения).

В основе метода - систематическое создание учителем проблемных ситуаций, постоянное побуждение учащихся к самостоятельной познавательной деятельности, демонстрация движения мысли от одного этапа познания к другому (учащиеся могут участвовать в прогнозировании следующего этапа рассуждения), иллюстрация логики этого движения, возникающие противоречия. Тем самым учащиеся знакомятся с процессом познания, включаются в него, соучаствуют.

Эффективность данного метода определяется степенью развития навыков критического мышления. 


\section{Годишник на ФХH, XXXII A}

3. Метод „Перевернутый класс“ („Три совета психолога новичку“, „Мы всегда стараемся выделяться“).

Это инновационный сценарий обучения, в котором теоретический материал изучается самостоятельно до начала урока, а высвобожденное время на уроке направлено на решение проблем, сотрудничество, взаимодействие с учениками, применение знаний и умений в новой ситуации, и на создание учениками нового учебного продукта.

Эффективность метода основывается на том, что ученик осваивает материал в индивидуальном темпе; существует возможность общаться со сверстниками и педагогом, используя систему онлайновых дискуссий, что создает очень спокойную атмосферу при освоении нового материала; все трудности в индивидуальном освоении снимаются при работе в классе.

4. Метод интегральной поэтики (Petrivnyaya i dr. 2020: 2) („Сердце Данко“, „Притча о характере человека“ и др.).

Метод, специально направленный на изучение литературы, в большинстве своем, в иноязычной аудитории. Это способ научной интерпретации художественных произведений, научная специфика которого заключается в синтезировании в единую сложную модель всех компонентов поэтики и методов, исследующих законы внутренней связи и соотношения различных уровней художественного целого.

Эффективность метода в том, что художественный текст рассматривается как максимально упорядоченное единство, выявляется богатство связей между его частями и становится понятным глубокое общезначимое, нравственное и мировоззренческое содержание произведения.

5. Memod CLIL (Content and Language Integrated Learning предметно-языковое интегрированное обучение в процессе преподавания) (Gel'frejh 2021: 3) (все художественные тексты).

Основные принципы метода связаны с изложением предметного содержания на иностранном языке, с овладением навыками межкультурной коммуникацией, устного и письменного общения, но на академическом языке предмета, с обязательным элементом когнитивного развития учащихся.

Эффективность метода заключается в современных формах взаимодействия преподавателя и обучающихся, с применением инновационных образовательных технологий.

6. Метод ролевых игр („Честное слово“ - драматизация, диалоги, „Как узнать способности?“ и др.). 


\section{Люба Станева. Рассмотрение свойств личности ...}

Основной особенностью ролевой игры является то, что ученику дается возможность самостоятельно и свободно действовать в конструируемой ситуации и, тем самым, получить опыт, обнаружить свое незнание или достигнуть понимания.

Основными образовательными результатами в использовании этого метода могут быть по мнению А. И. Федосеева ,развитие способностей коммуникации, рефлексии, развитие мышления; понимание сложной человеческой системы, воспитание и развитие человека через помещение в ситуацию самоопределения и ценностного выбора“" (Kruglikov 1998: 9).

7. Индуктивный/ дедуктивные методы (все тексты, на разных этапах изучения).

Первый метод включает переход от единичного знания к общему выводу, а второй - изложение общих принципов, понятий, усвоение которых позволит учащимся анализировать все частные варианты как их проявления.

Дедуктивный метод особенно полезно применять при изучении теоретического материала, при решении задач, требующих выявления следствий.

8. Частично-поисковый метод („,Что есть внутри проявляется снаружи“" продукция письменного текста, диалоги).

Выполнение задач с неполным условием, самостоятельное выполнение задач, т. е. метод подразумевает постановку вопроса таким образом, что учащиеся не получают „готовых знаний“, но активно участвуют в поиске решения, тем самым развивая свои способности к мышлению.

Эффективность метода основывается на возможности реализации творческой деятельности учащихся.

9. Метод (авто)рефлексии (все тексты, на разных этапах изучения).

В итоге работы необходимо акцентировать внимание учащихся на полученном опыте осмысления и сопереживания на уроке. Так окончательно учащиеся помещаются в нужный контекст понимания. В этом обобщении перед каждым по собственному пройденному пути происходит непосредственное раскрытие содержание материала.

Рефлексия помогает ученикам сформулировать получаемые результаты, осмыслить новые знания, переопределить цели дальнейшей работы, скорректировать свой образовательный путь. 


\section{Годишник на ФХH, XXXII A}

\section{Б. Технологии}

1. Технология критического мышления, цель которой научить критически мыслить - обсуждать, оценивать, выявлять и решать проблемы (все тексты).

Специфика авторской работы - отработка одной темы с использованием различных по сложности, длине и стилистике текстов, следуя последовательному расширению понятийного аппарата.

2. Технология Кейс-стади ("CASE STUDY“), цель которой осмысление содержания заключенной в предложенных материалах проблемы и предложение своего решения; совершенствование речевых навыков и умений учащихся в результате обсуждения проблемной ситуации („Воробей“, „Два товарища“, „Мы всегда стараемся выделиться“, диалоги по проблемным ситуациям, „Самая высокая радость в жизни - чувствовать себя нужным и близким людям“ и др.).

3. Технология Инфографика (Manzhura 2017:72), цель которой - визуализация в компактной форме учебной информации; стимуляция активности мышления; продуцирование собственного текста учащегося („Два волка“, „Самая высокая радость в жизни - чувствовать себя нужным и близким людям“, „Посеешь поступок - пожнёшь привычку, посеешь привычку - пожнёшь характер, посеешь характер пожнёшь судьбу“ и др.).

4. Технология проектов, цель которой - организация самостоятельной познавательной и практической деятельности; формирование широкого спектра умений работы в команде, умения конструктивно-критической самооценки; реализация творческого потенциала в исследовательской и предметно-продуктивной деятельности („Что такое характер? - мысли великих“).

\section{В. Приемы}

1. Приемы, способствующие созданию проблемных, поисковых ситуаций в мыслительной деятельности - постановка проблемных вопросов; подведение обучаемых к противоречию; изложение различных точек зрения на один и тот же вопрос; рассмотрение явления с различных позиций; побуждение делать сравнения, сопоставления, выводы; постановка задач с неопределенностью в постановке вопроса, с ограниченным временем решения. 


\section{Люба Станева. Рассмотрение свойств личности ...}

2. По способу логического умозаключения - анализ, синтез, сравнение, противопоставление, систематизация, обобщение, подведение итогов.

3. По характеру познавательной деятельности объяснение, беседа, самостоятельное решение задач

4. Приемы, активизирующие переживание - проблемная ситуация, связанная с опытом учащихся, соревнование, творческие задания.

Совместное использование данных методов, технологий и приемов обеспечивает последовательность развития основы мышления учащихся, а именно:

$\checkmark$ способность ставить новые вопросы;

$\checkmark$ вырабатывать разные аргументы;

$\checkmark$ принимать независимые продуманные решения.

Далее представлена конкретная работа с текстами на уроках РКИ в 8-ом классе с углубленным изучением русского языка школы имени А. C. Пушкина города Варна, Болгария. Формирование представления о многослойности пространства текстов и осмысление собственной реакции восприятия этих текстов учащимися - основные акценты в работе с учениками.

\section{Процесс рассмотрения свойств личности}

\section{1. „Ворона и рак”}

Русская народная сказка

Знакомство с литературной историей и культурой другой страны в возрасте 13-14 лет, на наш взгляд, удачно начинать с самого близкого и знакомого с детства, вобравшего в себе опыт и знания всего народа - со сказки.

Выбор пал именно на конкретный текст, т. к. он обладает несколькими важными характеристиками - краткость, доступность языка, особенно на первом месяце обучения, звукоподражательные и поэтому легковоспринимаемые слова, несложный сюжет, легкость прихода к выводам со стороны учеников.

I. Тип работы - аудирование аутентичного текста.

II. Порядок работы:

- выразительное зачитывание текста учителем; 


\section{Годишник на ФХH, XXXII A}

- работа над лексикой, например - ,славные были птицы! что за добрые были птищьы!“ - комментарий интонации, синонимичность конструкций, строение второй конструкции и проведение противопоставления болгарскому языку - „что за добри птици!”, в котором коннотация обычно отрицательная выражение показывает недоумение, недовольство, возмущение/; „да все же“ - эмоциональность фразы с частицей „же” знакомство с нюансами языка на начальном этапе обучения языку заостряет внимание учеников к способам высказывания на русском языке;

- устный перевод на родной язык - общее понимание текста;

- работа над содержанием - обсуждение причины поведения птицы;

- итоговое упражнение - сделать вывод о качествах героя сказки.

Сходным образом проходила работа и по рассказам Толстого „Два товарища““ и Ушинского „Два плуга“, которые тоже проходили как уроки аудирования, в которых литература рассматривалась как словесный вид искусства, отражающий материальную и духовную жизнь народа, нравственные ценности и идеалы. Проходило и обсуждение качеств личности, которые характерны для настоящей дружбы, для насыщенной и полнокровной жизни.

\section{2. „Два волка"}

Индейская притча

Характеристики текста:

- краткость, отсутствие сложностей в грамматическом и лексикальном отношении;

- формат текста - диалог - обеспечивает слушателю динамику восприятия;

- иносказательность дает возможность рассуждать над основными гуманистическими ценностями;

- возможность схематического представления идеи текста.

I. Тип работы - аудирование переводного текста.

II. Порядок работы и языковые области, в которых проходит обучение:

- выразительное зачитывание текста учителем (фонетика);

- ответы на вопросы по содержанию текста:

1. Что такое притча? (литературознание) 
2. Какой падеж у существительного „волк“ в заголовке притчи? (грамматика - Р.п. после числительного)

3. Где происходило действие? (грамматика - Пр. п.)

4. Кто с кем говорил в притче? ( грамматика - И. п., Тв. п.)

5. В чем видит старик добро в человеке? (грамматика - Пр. п.) (лексика - употребление слов, обозначающих отвлеченные х-ки качеств человека)

6. Почему именно в таком порядке он расположил эти положительные качества? (развитие речемыслительных навыков (анализ, синтез, сравнение) - высказывание собственного мнения)

7. Обсуждение инфографики (иллюстрация в графическом виде основной интерпретации текста) - Схема 4.

\section{Схема 4.}

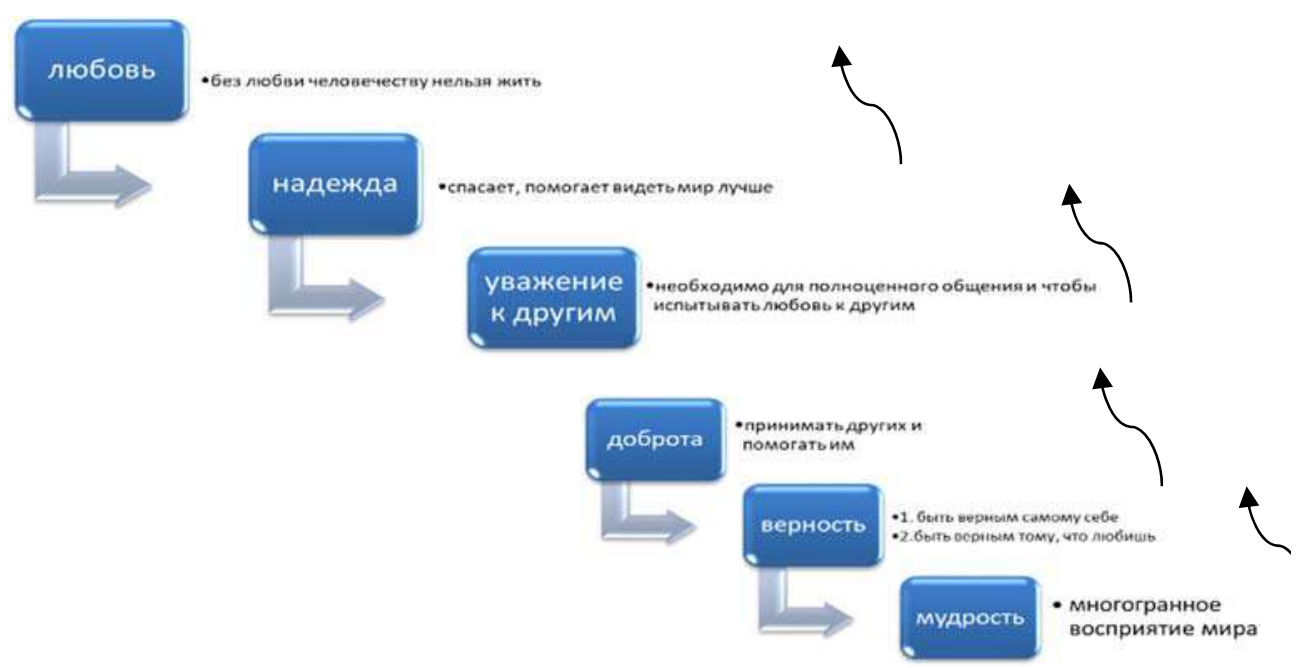

8. Почему амбиции указаны как зло в человеке? (развитие речемыслительных навыков (анализ, синтез) - высказывание собственного мнения)

9. Что означает, по-вашему, ответ старика на вопрос внука? (развитие речемыслительных навыков (анализ, синтез) - обсуждение и рассуждение)

10. Итоговое упражнение - оформите вывод притчи: вывод класса - „Ты сам каждый раз выбираешь быть добрым или злым.“, т.е. каждый 


\section{Годишник на ФХH, XXXII A}

день человек сам делает выбор между добром и злом и все зависит от него.

\section{3. „Воробей“6, И. С. Тургенев}

Стихотворение в прозе

Работа над адаптированным текстом происходила в порядке фонетического введения на уроке в 8-ом классе на 2-ом месяце работы с учениками, не изучавшими раньше русский язык.

Основные цели преподавателя - заинтересовать учеников сюжетом и вызвать обсуждение ситуации, что приводит к повышению мотивации учеников заниматься иностранным языком, воспитать высокие нравственные добродетели и предоставить возможность соприкоснуться с классической русской литературой и образцом звучания и строения текста на русском языке.

Выбор этого текста диктовало и понятие о том, что знакомство с русской культурой невозможно проводить без учета особенностей русской этнопсихологии и основные ее черты, на наш взгляд, как тончайшая чуткость, сердобольность, стремление к пониманию других, умение ценить красоту жизни должны быть первыми в строении образа русского в сознании учеников.

I. Тип работы - аудирование адаптированного текста.

II. Порядок работы:

- выразительное зачитывание текста учителем;

- короткий рассказ о стихотворениях в прозе;

- работа над лексикой, например, Охота, возвращзаться с охоты - слово, словоупотребление - знакомство со словом в разных падежах; Крылылики - словообразование и значение, эмоциональная окраска слова; Камнем упал = упал как камень - объяснение значения не путем перевода, а объяснительной конструкцией на изучаемом языке; устойчивое словосочетание; Заслонил собою, жертвовал собою перевод и вопрос о том в каких случаях делают это люди воспитательный элемент; Благоговея - перевод, через объяснение значения на родном языке - примеры употребления на родном языке благодаря совпадению звучания и значения слова в БЯ (болг. яз.) и РЯ (русск. яз.) расширение понятийного и лексикального запаса учеников и на родном языке;

- работа над содержанием текста - вопросы к тексту, например: Кто главный персонаж рассказа? Почему вы думаете так? Почему старый 
воробей „не мог усидеть на своей высокой, безопасной ветке”? Почему автор почувствовал глубокое уважение к старому воробью?

- итоговое упражнение: Скажите на болгарском языке, каково ваше мнение о поведении старого воробья и о заключении автора.

После беседы, обсуждения качеств главного героя истории и высказывания собственного мнения на родном языке, клас обобщил свои мнения и обобщенную фразу перевели на русский язык - „Силата на любовта /особено родителската/ побеждава всичко.” - „Сила любви /особенно родительской/ побеждает все."

\section{4. „Притча о характере человека“, неизвестный автор Притча}

При выборе текста руководящими были следующие факторы:

- троекратность повторения ситуации, языковых конструкций, возможность проследить как нюансы в лексике влияют на изменение смысла;

- иносказательность текста;

- возможность рассуждать над категориями нравственности (впервые появляется термин „характер“);

- возможность проверить автоматизацию знаний по падежной системе русского языка.

I. Тип работы - аудирование и диктант.

II. Порядок работы на уроке:

- чтение текста учителем целиком для восприятия идеи текста;

- чтение текста в режиме диктанта;

- трое учеников собирают диктанты одноклассников по рядам;

- проверка особенностей написания слов в тексте, уточнение значения лексики;

- обсуждение содержания понятия „характер“;

- беседа о категориях нравственности вообще и затронутых в частности в тексте;

- итоговое упражнение - выявить свое мнение по данному в притче выводу.

III. Проверка и оценка преподавателем диктанта текста.

5. „Как узнать способности?“, А. Лопатина

Научно-популярная статья 


\section{Годишник на ФХH, XXXII A}

Текст привлек возможностью, читая вдумчиво, построчно с учениками, помочь им порассуждать самим, в чем связь между внутренним строем мысли, стержнем личности и внешним поведением, поступками, не забывая об особенностях русского языка - в данном случае обилие наречий.

I. Тип работы - чтение. Текст читается самими учениками выразительно в ролях.

II. Порядок работы:

- задавая неоднозначные вопросы по содержанию, преподаватель стремится помочь ученикам самим прийти к выводу о главной идее текста - „Что есть внутри, обязательно проявится снаружи“ и не только комментировать данный текст, но и соотнести сказанное с собственными качествами, поступками, намерениями, т.е. появляется возможность применить авторефлексию;

- итоговое упражнение - работа над текстом плавно перелилась в работу над выражением своих мыслей по этой теме на письме.

\section{6. „Что есть внутри проявляется снаружи“6}

Продукция собственного текста на письме

В таком типе работы для учеников очень важно, по нашему мнению, применить приемы анализа и синтеза исходного текста, над которым рассуждать, упорядочить собственные мысли и прийти к собственным выводам по отношению к идее текста, и использовать знания о структурировании сочинения-рассуждения.

Алгоритм работы преподавателя над сочинениями на начальном этапе обучения:

1. Работа с учениками над лексикой и грамматикой по теме;

2. Обсуждение темы, аргументация того или иного мнения, беседа, дискуссия на уроке;

3. Написание I варианта сочинения учениками;

4. I вариант коррекции учителя с письменным обсуждением последовательности изложения мысли, достаточно объемного освещения вопроса, стиля работы;

5. Написание II варианта сочинения;

6. II коррекция и последующие комментарии учителя (где это необходимо, возможен и III вариант, цель - показать ученику на примере его способа мышления как лучше организовать свое изложение мысли, 
подобрать подходящую аргументацию, обсудить ошибки в лексическом, грамматическом, стилистическом отношении);

7. Оценка по определенным критериям - соответствие теме, логичность и последовательность аргументации, соблюдение объема, подсчет лексикальных, грамматических, стилистических ошибок и т. д.

\section{7. „Три совета психолога новичку“, „Мы всегда стараемся выделяться"}

Научно-популярные статьи

Тексты предоставляют ученикам познакомиться подробнее с научно-популярным стилем изложения мыслей на русском языке в статьях, ознакомиться с категорией СВ и НСВ вида и порассуждать над важными для них темами об адаптации в новом классе и о способах выделяться в компании.

I. Тип работы - чтение

II. Порядок работы:

- чтение учениками вслух (работа над фонетикой учащихся);

- работа над грамматической категорией вида глагола;

- ответы на вопросы по содержанию, например: „В чем схожи поведение человека и обезьяны? Как выделяются подростки обычно?“, „Что означает стремление подростков выделиться любым способом?“, „По-вашему, со знаком „Плюс“ или со знаком „минус“ можно охарактеризовать это стремление выделиться любым способом?“;

- итоговое упражнение: напишите в тетради ответ на вопрос „Как вы выбираете выделяться?”.

\section{5. Тема „Поведение человека“}

Продукиия собственного текста в устной речи - диалоги Заданные ситуации:

1. Вы стали свидетелем грубости. Опишите ситуацию и обсудите поведение человека с другом.

2. Вы стали свидетелем человечности молодой девушки. Опишите ситуацию и обсудите с коллегой по физике еe поступок.

3. Вы стали свидетелем равнодушия человека. Опишите ситуацию и обсудите ее со своим ребенком.

Возможность продумать, прочувствовать реальную ситуацию, в которой нужно выработать и высказать на иностранном языке свою 


\section{Годишник на ФХH, XXXII A}

позицию по важным нравственным вопросам стала заключительным, рефлективным этапом работы над основной темой, рассматривающей поведение и характеристики человека.

\section{Погружение в тему „Характер“}

Уже имея достаточно знаний по языку для пространного и содержательного разговора, в котором высказать и аргументировать свое понимание, учащиеся смогли справиться со следующим по сложности заданием учителем - на нескольких уроках развития речи углубиться в поиски ответа на вопрос - ,А А что такое характер?““

Последовательность погружения в тему - Схема 5., осуществилась на примере разнообразных текстов, которые обладают разными характеристиками в содержательном плане и демонстируют характеристики разных жанров текста:

1. личное мнение (цитата);

2. легенда;

3. рассказ, придуманный автором;

4. статья - рассказ о реальном человеке.

Схема 5.

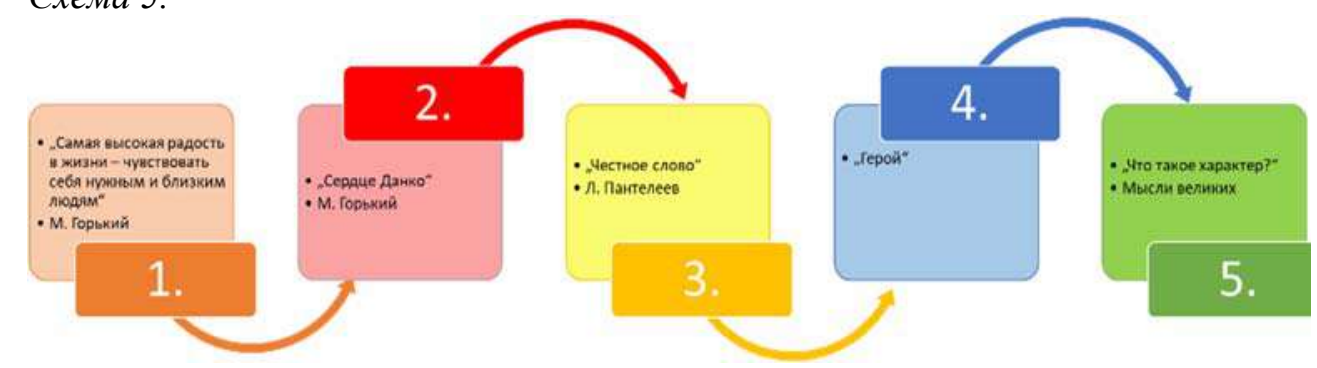

Рассмотрение мнения великих личностей по теме в конце цикла возвращает учащихся к особенностям личного восприятия данного понятия, дает возможность уже на новом уровне рассуждать над проявлением данной характеристики человеческого поведения, соотнести свои взгляды со взглядами людей, живших в разные века, прийти к выводу о вневременности темы.

Эта последовательность обеспечила не только знакомство с новыми формами языка по нарастающей сложности, но и постепенно, в ходе занятий, содействовала формированию основных мировоззренческих идей, определенных нравственных устоев, связанных 
с проявлением смелости, стойкости, самопожертвования, совершения подвига.

І урок - Работа с текстом-предложением (мнение автора)

Чтение текста

На данном уроке была рассмотрена цитата Максима Горького „Самая высокая радость в жизни - чувствовать себя нужным и близким людям.“" как подготовка к аудированию следующего текста. Деятельность на уроке следовала определенной последовательности, в которой имели место перевод, лексикальная и когнитивная догадка, работа со словарем, дискуссия по выявленным из текста понятиям, поиск семантической связи слов для более точной передачи желанного смысла, а также парная работа для создания собственной инфографики, раскрывающей основной смысл высказывания через словосочетание „самая высокая радость“Илл.1.

Илл. 1.

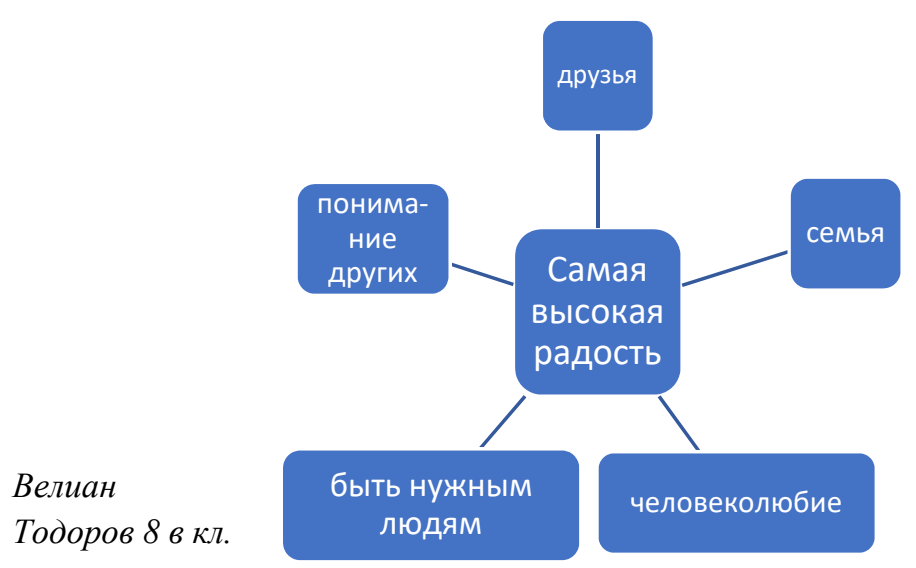

Итоговым упражнением стал короткий ответ на вопрос „Согласны ли вы с писателем и почему?“ - продукция собственного текста.

II, III, IV урок - Работа с текстом „Сердие Данко“ Горького. Аудирование адаптированного текста по частям.

Здесь ученикам было предложено решать тест по аудированию с закрытыми и открытыми ответами (свободный ответ на вопрос, в котором нужно высказать суждение), сформулировать в одном предложении основное содержание каждой части (анализ и синтез мышления), заняться переводом предложения, в котором присутствовала 
незнакомая до того момента грамматическая форма (лингвистическая и семантическая догадка), работа с ключевыми словами в тексте и выявление собственного мнения в условиях мозгового штурма, поиск причины именно такого поведения героев, работа над содержанием ключевой для понимания поведения главного героя фразы в целом тексте, работа с лексикой при составлении характеристики Данко, составление плана всего текста и др.

Итоговыми заданиями были короткое изложение легенды о Данко и ответ на вопрос: „В чем сила Данко?““ (10 предложений) - Илл. 2.

\section{Илл. 2.}

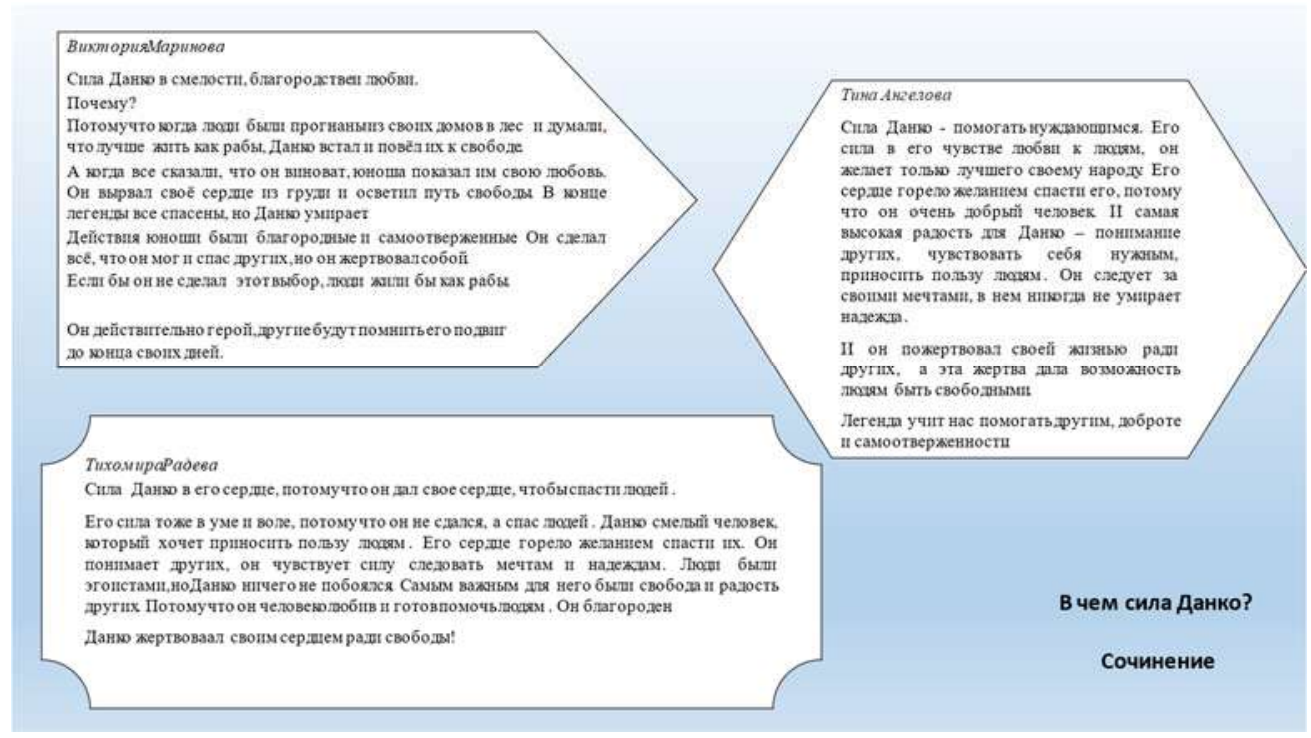

\section{$\boldsymbol{V}$ урок - Работа с текстом „Честное слово“ Леонида} Пантелеева

Чтение текста учителем и учениками (драматизаџия)

Тут тоже была проведена работа над фонетикой и лексикой, над грамматикой и содержанием одновременно - пополнить пробелы в предложениях сообразно тексту, перевод. Вопросы по содержанию были оформлены так, чтобы вызывать оценку действий героев у учеников. Важным было и выявить отношение читающих к проявлению характера героев. Впервые внимание учеников было направлено на формирование эмпатии и устойчивой нравственной позиции в сложной ситуации. 
VІ урок - Работа со статьей „Герой“

Аудирование текста (увеличивается длина текстов, воспринимаемая на слух)

Работа по тексту шла обычным уже путем, но здесь был сделан акцент на рассмотрение условий совершения реального подвига, расширилась (при обсуждении) возможность лучше понимать героический поступок человека, была проведена рефлексия (Хотели бы вы совершить подвиг? Ответьте себе сами и подумайте почему так отвечаете.)

VII урок - Черты характера

Говорение - индивидуальная работа в условиях состязания

Следующая работа над знакомой темой была связана с обобщением уже знакомого языкового материала, связанного с чертами характера.

Наращение лексикального запаса происходило при работе над синонимами и антонимами, над объяснениями фразеологических оборотов, которые ученикам надо было употреблять в определенном контексте.

УІІІ урок- Мысли великих

Говорение и письмо - групповая работа

На основе мыслей о характере Сенеки, Гюго, Монтескье, Шоу, Поваляева (писателя, философов, драматурга) ученики группами, образованными по решению учителя, рассуждали над литературным переводом на болгарский язык определенной мысли, над объяснением ее значения, над тем, о каких качествах человека идет речь в высказывании великих. Каждая группа выбирала представителя, который презентировал работу группы, оглашал и обобщал ответы учащихся в группе на следующий вопрос „Согласны ли вы с мнением вашей группы?“.

Итоговой работой стало сочинение на тему „Расскажите о характере любимого человека““ (сочинение - 10 предл.).

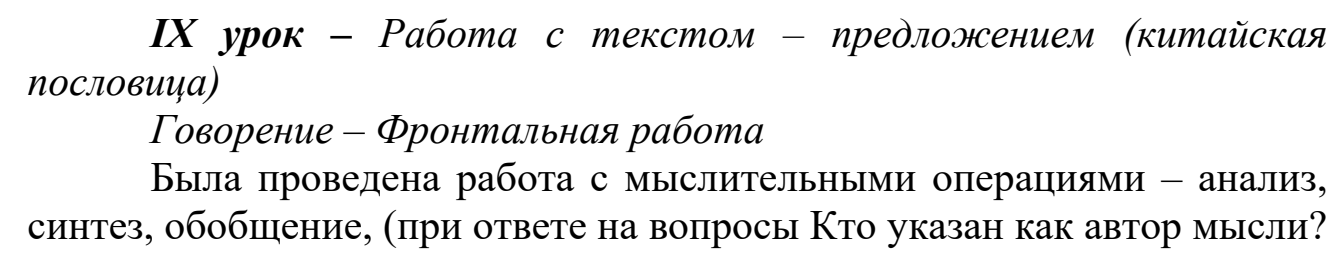




\section{Годишник на ФХH, XXXII $A$}

Какой вывод о значимости мысли можем сделать, имея ввиду автора и его национальность?). Ученики искали лучший правильный перевод пословицы „,Посеешь поступок - пожнёшь привычку, посеешь привычку - пожнёшь характер, посеешь характер пожнёшь судьбу “ и был сделан вывод о разнице в наклонении на болгарском и русском языке, т.е. повысилась языковая компетенция учеников, и они познакомились с особенностями переводческих трансформаций, связаных с вопросами семантики, грамматики, синтаксиса, рассуждали над употреблением слов в прямом или переносном значении, что формирует вдумчивое отношение к слову вообще. Ученики рассуждали и над вопросом о значении и связи слов поступок (действие один раз), привычка (много раз) и характер (всю жизнь) и пришли к выводу, что смысл пословицы в том, что человеку надо думать о своих поступках и о последствиях от них, потому что это определит его жизнь и судьбу. Работа над этим коротким текстом, на наш взгляд, привела к формированию устойчивого понимания взаимосвязи между выбором человека и его действиями и его характером.

\section{Хурок - Урок лексики (обобщение)}

Говорение (беседа)

При работе на этом уроке происходило обсуждение лексики по данной таблице, определение значения слов (сходных по звучанию - по знаниям об их значении в болгарском языке); комментарий положительности и отрицательности качеств.

Самая основная работа здесь была проделана по формулировке значений понятий, т.к. было установлено, что не каждый ученик ясно понимает значение определенного понятия (было использовано деление качеств характера по системе Б. М. Теплова) (Происходило интенсивное расширение понятийного аппаратата подростков)- Схема 6.

\section{Схема 6.}

\begin{tabular}{|l|l|}
\hline \multicolumn{1}{|c|}{ Отношение } & \multicolumn{1}{|c|}{ Качества характера } \\
\hline 1. К людям & вежливость - грубость; \\
& общительность - замкнутость; \\
& альтруизм - эгоизм; \\
& тактичность - бестактность; \\
& чуткость- жестокость; \\
& искренность - лицемерие; \\
& доброжелательность - зависть; \\
\hline
\end{tabular}




\begin{tabular}{|l|l|}
\hline & бескорыстность - жадность; \\
& доброта - злобность; \\
& верность - непостоянство; \\
& принципиальность - беспринципность; \\
оптимизм - пессимизм
\end{tabular}

Заключительным уроком по теме стал $\boldsymbol{X I}$ урок - Анкета „Какой характер будешь сеять, восьмиклассник?"

Письмо, Чтение, Говорение

На этом уроке был продемонстрирован весь накопленный языковой, понятийный, интеллектуальный запас учеников при ответе на вопросы:

1. Знаете вы ли свой характер и самого/саму себя?

2. Довольны ли вы характером?

3. Занимаетесь ли вы самовоспитанием?

4. Может ли человек сам выработать свой характер?

5. Какие черты характера вы бы хотели выработать у себя? (пользуйтесь табличкой из предыдущего урока и выберите пять самых важных свойств, которые вам надо выработать у себя и прочитайте про себя самое важное для вас)

Итоговая работа (устная и письменная) на уроках, связанных с темой о свойствах личности, выявила все успехи учеников в освоении лексикального, грамматического, синтаксического строя русского языка в первый год обучения языку, показала достигнутое в освоении лингвокультурной компетенции, в развитии познавательной компетенции. Важно отметить, что развитие компетенций происходило в режиме диалогичности, что привело и к эволюции критического мышления и этических норм обучаемых. Была доказана возможность активной и эффективной работы с художественным и учебным текстом 


\section{Годишник на ФХН, XXXII A}

на высоком уровне еще на начальном этапе обучения языку в старшей школе на основе определенной последовательности в работе с текстами.

Предложенная последовательность авторских упражнений обеспечила актуальность тем, диалогичность занятий, повышение мотивации изучения языка и самостоятелность в работе учеников.

Разнообразие предложенных текстов и упражнений к ним, способствовало индивидуализации учебного процесса, когда в процессе комментирования каждый мог ознакомится с до тех пор не обсужденной им темой и своим темпом формировать конечную позицию, точку зрения, которая, может быть, окажет влияние на его жизнь вдальнейшем. Неодинаковость характеристик текстов предоставила возможность создать и фундаментальную основу межпредметного образовательного процесса - через текст и язык осуществилось взаимодействие с литературой, историей, психологией, философией, актерским мастерством, математической моделью, ИКТ и др.

Таким образом, на наш взгляд, было доказано, что текст явяется основой для создания развивающей среды на уроках иностранного языка.

Постепенное введение в мир русского языка через текст следовало принципу дедукции/индукции (в зависимости от сложности понятий в теме) и предлагало различные возможности для выполнения логических операций, способствовало созданию умения критически мыслить и познавать мир и человеческую личность, развивало когнитивную компетенцию учащихся.

Повышенная самостоятельность при работе со словарем, в поисках личной позиции по важным вопросам, спокойствие высказывать свои мысли, не боясь ответной реакции, помогло ученикам приобрести уверенность в своих знаниях языка, в формировании собственной позиции, в высказывании своего мнения по важным нравственным вопросам и заняться творчеством. Она побуждала учеников к познанию собственной личности, к изучению собственного образа мышления и поведения.

Подобранные концентры программы и занятий давали возможность в альтернативной форме стимулировать аргументативное мышление учеников.

Ученик, при такой последовательности преподнесения материала и упражнений, превращался в активного участника учебного процесса, используя средства языка, которыми овладевал по нарастающей сложности, рассуждая над актуальными для него темами, формируя представление о собственных нравственых нормах. 
В результате проделанной работы нужно сделать следующее обобщение: задачи, которые стоят и перед учителем иностранного языка - развивать, расширять грамотность (особенно функциональную) и воспитывать - диктуют одновременность работы в двух основных направлениях:

1. осуществлять когнитивное развитие на иностранном языке:

- развитие общего уровня осведомленности учеников, способности к восприятию, сборе и обработке информации, что связано со стимуляцией познавательной деятельности на иностранном языке;

- быстрое выявление закономерностей и использование различных логических операции, что сопутствует развитию умений активно формулировать и защищать личную позицию на иностранном языке.

2. осуществлять воспитательную цель обучения на иностраном языке:

- на основе ценностно-ориентированного и контекстного знания необходимо расширять понятийный аппарат и формировать моральные устои подростков.

Это приводит к формировании культуры мышления (в том числе и на иностраном языке), которая даст возможность обучаемому принимать адекватные, ответственные решения, которая побуждает творческую и конструктивную деятельность и создает личность, отвечающую беспрестанно меняющимся условиям существования, что и является основной задачей, с нашей точки зрения, школы сегодня.

Дальнейшие поиски новых решений всех этих сложных методических и педагогических задач требуют рассмотрения вопроса о познании мира через познание языка на уроке РКИ в болгарской школе (об одновременом развитии когнитивной, лингвокультурной, коммуникативной компетенции на иностранном языке) с точки зрения этики, психологии, педагогики, нейролингвистики, текстолингвистики, информационых технологий, т. е. требуют интердисциплинарного подхода. Это позволит создать комплексы уроков и мероприятий на уроке по развитию коммуникативных универсальных учебных действий и формированию познавательной компетенции обучаемых.

\section{REFERENCES}

Brodzeli 2017: Brodzeli, A. O. Hudozhestvennaya literatura $v$ obuchenii RKI (metodicheskie rekomendatsii). - Universitetskie chteniya - 2017. Materialyi nauchno-metodicheskih chteniy PGU.: Pyatigorskiy gosudarstvennyiy 


\section{Годишник на ФХH, XXXII A}

universitet (Pyatigorsk), s. 92-98 [Бродзели, А. О. Художественная литература в обучении РКИ (методические рекомендации). Университетские чтения - 2017. Материалы научно-методических чтений ПГУ.: Пятигорский государственный университет (Пятигорск), c. 92-98].

Evdokimova 2018: Evdokimova, M. G. Kognitivnyie i metakognitivnyie stategii ovladeniya inostrannyim yazyikom. Sovremennyie tendentsii razvitiya sistemyi obrazovaniya. Sbornik trudov Mezhdunarodnoy nauchnoprakticheskoy konferentsii. Cheboksary: Obschestvo s ogranichennoy otvetstvennostyu „Izdatelskiy dom „Sreda“ [Евдокимова, М. Г. Когнитивные и метакогнитивные стратегии овладения иностраннывм языком. Современные тенденции развития системы образования. Сборник трудов Международной научно-практической конференции. Чебоксары: Общество с ограниченной ответственностью „Издательский дом „Среда“].

Fedoseev: Fedoseev, A. I. Rolevyie igryi kak obrazovatelnaya tehnologiya [Федосеев, А. И. Ролевые игры как образовательная технология] $<$ https://thenoon.ru/files/documents/file_3554df3ee195153955f5e13142223 022.pdf (status_26.08.2021)>.

Gelyfreyh 2021: Gelfreyh, P. CLIL. Osnovnyie printsipyi i terminologiya. CLIL for RUSSIAN LANGUAGE (science for primary school; history, geography, literature for childrenand adults) [Гельфрейх, П. CLIL. Основные принципы и терминология. CLIL for RUSSIAN LANGUAGE (science for primary school; history, geography, literature for childrenand adults)].

Ivanov 2005: Ivanov, I. Interaktivni metodi na obuchenie. // Yubileyna nauchna konferentsiya s mezhdunarodno uchastie 50 godini DIPKU - Varna na tema: „Obrazovanie i kvalifikatsiya na pedagogicheskite kadri - razvitie i proektsii prez XXI vek“. Varna [Иванов, И. Интерактивни методи на обучение. //Юбилейна научна конференция с международно участие 50 години ДИПКУ - Варна на тема: „Образование и квалификация на педагогическите кадри - развитие и проекции през XXI век“. Варна].

Kruglikov 1998: Kruglikov, V. N. Aktivnoe obuchenie v tehnicheskom vuze: teoriya, tehnologiya, praktika - Sankt-Peterburg: Voennyiy inzhenerno-tehnicheskiy universitet - 308 s. [Кругликов, В. Н. Активное обучение в техническом вузе: теория, технология, практика - Санкт-Петербург: Военный инженерно-технический университет -308 с.].

Kryimskiy 1992: Kryimskiy, S. B. Konturyi duhovnosti: Novyie kontekstyi identifikatsii // Voprosyi filosofii. 12, s. 21-28 [Крымский, С. Б. Контуры духовности: Новые контексты идентификации // Вопросы философии. № 12, c. 21-28].

Kulibina 2013: Kulibina, N.V. Uroki chteniya kak sposob sohraneniya duhovnogo naslediya. Tekstyi lektsiy i obraztsyi urokov (dlya prepodavateley russkogo 
yazyika kak inostrannogo). Vyip. 2. Moskva: Gos. IRYa im. A. S. Pushkina, s. 64-80 [Кулибина, Н. В. Уроки чтения как способ сохранения духовного наследия. Тексты лекций и образцы уроков (для преподавателей русского языка как иностранного). Вып. 2. Москва: Гос. ИРЯ им. А. С. Пушкина, с. 64-80].

Lozanov 1973: Lozanov, G. Problemi na sugestologiyata. Sofia: Nauka i izkustvo, s. 55-70. [Лозанов, Г. Проблеми на сугестологията. София: Наука и изкуство, с. 55-70].

Lozanov 1977: Lozanov, G. Suschnost, istoriya i eksperimentalnye perspektivy suggestopedicheskoy sistemy pri obuchenii inostrannyim yazykam. // Metodyi intensivnogo obucheniya inostrannyim yazyikam. Vyp. 3. Moskva, s. 7-16 [Лозанов, Г. Сущность, история и экспериментальные перспективы суггестопедической системы при обучении иностранным языкам. // Методы интенсивного обучения иностранным языкам. Вып. 3. Москва, с. 7-16].

Lozanov, Gateva 1981: Lozanov, G., E. Gateva. Sugestopedichno praktichesko rakovodstvo za prepodavateli po chuzhdi ezitsi. Sofia: Nauchnoizsledovatelski institut po sugestologiya [Лозанов, Г., Е. Гатева. Сугестопедично практическо ръководство за преподаватели по чужди езици. София: Научноизследователски институт по сугестология].

Manzhura 2017: Manzhura, L. N. Infografika kak odin iz metodov vizualizatsii uchebnogo materiala. // Sankt-peterburgskiy obrazovatelynyy vestnik, s. 7274 [Манжура, Л. Н. Инфографика как один из методов визуализации учебного материала. // Санкт-петербургский образовательный вестник, c. 72-74].

Neustroeva 2016: Neustroeva, T. M. Razvitie i vospitanie duhovno-nravstvennyih kachestv sredstvami predmeta „Inostrannyiy yazyik“. // Kulytura. Duhovnosty. Obschestvo, № 26, s. 39-42 [Неустроева, Т. М. Развитие и воспитание духовно-нравственных качеств средствами предмета „Иностранный язык“. // Культура. Духовность. Общество, № 26, с. 3942].

Nikitin 1980: Nikitin, A. F. Otvetstvennost nesovershennoletnih. Posobie dlya uchaschihsya. Moskva: Prosveschenie [Никитин, А. Ф. Ответственность несовершеннолетних. Пособие для учащихся. Москва: Просвещение].

ODK 2000: Bezrukova, V. S. Osnovyi duhovnoy kulturyi (entsiklopedicheskiy slovary pedagoga). Ekaterinburg: Ekaterinburg, 2000, s. 696 [Безрукова, В. С. Основы духовной культуры (энциклопедический словарь педагога). Екатеринбург: Екатеринбург, 2000, с. 696].

Passov, Kuzovleva 2010: Passov, E. I., N.E. Kuzovleva. Osnovyi kommunikativnoy teorii i tehnologii inoyazyichnogo obrazovaniya. Metodicheskoe posobie dlya prepodavateley russkogo yazyika kak inostrannogo. Moskva: Russkiy yazyik. Kursyi, 568 s. [Пассов, Е. И., Н. Е. Кузовлева. Основы коммуникативной 


\section{Годишник на ФХH, XXXII A}

теории и технологии иноязычного образования Методическое пособие для преподавателей русского языка как иностранного. Москва: Русский язык. Курсы, 568 с.].

Petrivnyaya et al. 2020: Petrivnyaya, E. K, E. G. Iyulskaya, A. A. Solomonova. Metodika $\mathrm{i}$ tehnologiya obucheniya russkoy literature $\mathrm{v}$ inostrannoy auditorii, kurs [Петривняя Е. К., Е. Г. Июльская, А. А. Соломонова. Методика и технология обучения русской литературе в иностранной аудитории, курс].

Piazhe 2004: Piazhe, Zh. Psihologiya intellekta. Sankt Peterburg: Piter [Пиаже, Ж. Психология интеллекта. Санкт Петербург: Питер].

Podlasyy 2004: Podlasyy, I. P. Pedagogika: 100 voprosov - 100 otvetov: ucheb. posobie dlya vuzov Moskva: VLADOS-press, 2004, 365 s. [Подласый, И. П. Педагогика: 100 вопросов - 100 ответов: учеб. пособие для вузов Москва: ВЛАДОС-пресс, 2004. 365 с.].

Rubinshteyn 2002: Rubinshteyn, S. L. Osnovyi obschey psihologii. Sankt Peterburg: Piter [Рубинштейн, С. Л. Основы общей психологии. Санкт Петербург: Питер].

Solso 2006: Solso, R. Kognitivnaya psihologiya. Sankt Peterburg: Piter [Солсо, P. Когнитивная психология. Санкт Петербург: Питер].

Staneva 2018: Staneva, L. D. Lichnyy arhiv [Станева, Л. Д. Личный архив].

Teplov: Teplov, B. M. Psihologicheskaya harakteristika lichnosti [Теплов, Б. М. Психологическая характеристика личности] $<$ http://seychaz .ru/psixologicheskaya-xarakteristika-lichnosti.html (status 08.09.2021)>.

Ter-Minasova 2000: Ter-Minasova, S. G. Yazyk i mezhkulturnaya kommunikatsiya: Ucheb. posobie dlya studentov, aspirantov i soiskateley po spets. „Lingvistika i mezhkulturnaya kommunikatsiya“. Moskva: Moskva 2000, s. 255 [TepМинасова, С. Г. Язык и межкультурная коммуникация: Учеб. пособие для студентов, аспирантов и соискателей по спец. „Лингвистика и межкультурная коммуникация“". Москва: Москва 2000, с. 255].

Velichkovskiy 2008: Velichkovskiy, B. M. Kompyuteryi, mozg i poznanie: Uspehi kognitivnyih nauk (sovm. s V. D. Solovyovyim). Moskva: Nauka [Величковский, Б. М. Компьютеры, мозг и познание: Успехи когнитивных наук (совм. с В. Д. Соловьёвым). Москва: Наука].

Vlasova 1999/2005: Vlasova, T. I. Pedagogika duhovnosti kak nauka i aktualizirovannaya praktika. // Problemyi kulturyi i vospitaniya, 4, s. 39-42/ Duhovno orientirovannaya model sovremennogo vospitaniya // Sovremennyie modeli vospitaniya $\mathrm{v}$ usloviyah diversifikatsii obrazovatelnogo prostranstva: Tezisyi uchastnikov $\mathrm{v}$ programma letney nauchnoy shkolyi - Tver, s. 29-31 [Власова, Т. И. Педагогика духовности как наука и актуализированная практика. // Проблемы культуры и воспитания № 4, с. 39-42 /Духовно ориентированная модель современного воспитания// Современные модели воспитания в условиях 
диверсификации образовательного пространства: Тезисы участников и программа летней научной школы - Тверь, с. 29-31].

Vyigotskiy 2005: Vyigotskiy, L. S. Orudie i znak v razvitii rebenka. // Pedagogicheskaya psihologiya. Moskva: AST: Astrel [Выготский, Л. С. Орудие и знак в развитии ребенка. // Педагогическая психология. Москва: АСТ: Астрель].

Zhelyazkova 2018: Zhelyazkova, Z. D. Izpolzvaneto na strategii za povishavane na efektivnostta v chuzhdoezikovoto obuchenie. - Godishnik na Pedagogicheski fakultet, Trakiyski universitet. Stara Zagora, s. 90 [Желязкова, 3. Д. Използването на стратегии за повишаване на ефективността в чуждоезиковото обучение. - Годишник на Педагогически факултет, Тракийски университет. Стара Загора, с. 90]. 